\title{
Transpiration from an Amazonian rainforest calculated from stomatal conductance measurements
}

\author{
John Roberts ${ }^{*}$, Osvaldo M R Cabral ${ }^{\mathrm{b}}$, G Fisch, L C B Molıon ${ }^{\mathrm{d}}$, C J Moore \\ W J Shuttleworth ${ }^{\mathrm{A}}$ \\ 'Institute of Hidrolog, W'allingtord $O \times 108 B B \cup \mathrm{K}$ \\ ${ }^{\mathrm{h}}$ EMBRAPA Manaus Amazonas Brazll \\ 'Centro Technuco Aeroespacial Sao Jose dos Campos Sao Paulo Brazal \\ 'Instituto Nacional Pesquisas Espacials Sao Jose dos Campos Sao Paulo Brazal
}

(Received 8 September 1992 revision accepted 3 March 1993)

\begin{abstract}
A mult-ldyer combination equation has been used to calculate transpiration from a tropical rainforest in the central Amazon, Brazll The five-layer formulation used through-canopy medsurements of temperdture and humidity deficit with leaf stomatal and boundary layer conductances scaled up to canopy layer values used a profile of canopy leaf area index derived from the literature Net radiation input to each layer was estimated from an above canopy medsurement using an extınction function and ledf ared index

Transpiration calculated for hourly and dally periods in a range of sedsond conditions agreed well with those measured directly with an eddy correlation device Four simplitied forms of the transpiration calculdtion were also compared with the direct medsurement These simplified forms used the above-canopy or the average of the through-canopy values of weather varlables and used either the average of leaf conductances multiplied by total leaf area index or the average of the layer conductances These simplified forms of the transpiration calculation gave poorer agreement with measured transpiration
\end{abstract}

\section{Introduction}

Complete or partial clearance of tropical rainforest affects large-scale surface energy balance and carbon dioxide content of the atmosphere, as well as local streamflow and soil stability The consequences of changes in the extent of tropical forests have been difficult to assess because of a shortage of information and understanding of the water, carbon and nutrient cycles of different forest types (Mooney et al, 1980)

In the last decade, however, there has been a substantial increase in the number of physiological studies of rainforest species, some of which have included detailed studies of leaf gas exchange and associated weather var1-

\footnotetext{
${ }^{*}$ Corresponding author
} 
ables throughout the height profile of the forest canopy (e g Oberbauer et al . 1987, Roberts et al , 1990) The data derived in such studies have at least a two-fold value Firstly, direct studies of stomatal behaviour, leaf gas exchange and their interaction with weather variables and soil water status can aid interpretation and modelling of water and $\mathrm{CO}_{2}$ fluxes determined micrometeorologically, and in this way and the redlism of hydrological and Global Climate modelling exercises (e g Shuttleworth, 1988, Sellers et dl, 1989) Secondly, the physiological data on stomatal and boundary-layer conductances and leaf area index can be used to provide d direct estimate of transpiration from rainforest canopies

As micrometeorological measurement of transpiration fluxes from vegetdtion can be expensive and time-consuming for tall forest canopies, there is merit in evaluatıng the scope for exploitıng existıng physiological datd for tropical ranforests to estimate transpiration using combination formulae in which these physiological data can be used in association with measured weather variables Although such combindtion formulae (e g Monteith, 1965) are now widely used for crops and other simple vegetation covers, their applicability to complex tropical rainforest canopies remains untested

The objectives of the studies presented here are three-fold, namely (1) to evaluate a multi-layer version of the Monteith-Penman formula which incorporates physiological and micrometeorological data taken at a primary rainforest site in the central Amazon against direct measurements of transpiration made at the same site, (11) to determine the relative importance of different input variables for such an equation, (111) to dssess the validity of simplifying this multılayer approach towards combination formulae of increasing simplicity

\section{Materials and methods}

Site

The experimental site was in terra firme forest in the Reserva Florestal Ducke, $25 \mathrm{~km}$ from Manaus, Amazonas, Brazll $\left(2^{\circ} 57^{\prime} \mathrm{S}, 59^{\circ} 57^{\prime} \mathrm{W}\right)$ The tallest emergent trees were about $40 \mathrm{~m}$ high, with the average height of the main tree canopy about $30 \mathrm{~m}$ No distınct layering exists in the forest canopy

A $44 \mathrm{~m}$ high sectional aluminium tower was installed in the forest on which micrometeorological equipment were mounted through and above the forest canopy (Shuttleworth et al , 1984a, b) Plant physiological measurements were made on foliage accessible from the tower, and on shorter vegetation at ground level within $100 \mathrm{~m}$ of the tower (Roberts et al , 1990)

\section{Microclimate}

The microclimate measurements used in the present study were above- 
canopy solar and net radiation, and the dry and wet bulb temperatures of the air measured with fully ventilated and shielded quartz-crystal psychrometers of the type described by Gash and Stewart (1975) The data used comes from a psychrometer mounted above the canopy at $44 \mathrm{~m}$, and others at 357,305 . 232,135 and $14 \mathrm{~m}$ above the forest floor within the forest Hourly average values were used in all the following analyses

\section{Multı-layer transpiration model}

\section{Model framework}

Total transpiration $(T)$ for the forest canopy was estımated by summing calculated fluxes given by the Penman-Monteith formulation

$$
\lambda T_{\imath}=\frac{\Delta_{l}^{\prime}\left(R_{\mathrm{n} l-1}-R_{\mathrm{n} l}+\rho c_{\mathrm{p}}\left(\delta q_{l}\right) g_{\mathrm{a} l t}\right.}{\Delta_{l}^{\prime}+\left(c_{\mathrm{p}} / \lambda\right)\left(1+g_{\mathrm{d}, l} / g_{\mathrm{c} \imath}\right)}
$$

applied at each of the five levels in the canopy In the above equation $R_{\mathrm{n} l-1}-R_{\mathrm{n}_{l}}$ is the radiatıve energy absorbed by the $t$ th layer of the forest, $c_{\mathrm{p}}$ is the specific heat of air at constant pressure, $T_{1}$ is the canopy layer transpiration rate, $g_{\mathrm{d}, t}$ is canopy layer boundary-layer conductance, $g_{\mathrm{u}}$ is canopy layer stomatal conductance, $\delta q_{1}$ is canopy layer specific humidity deficit, $\Delta^{\prime} l$ is the rate of change of saturated specific humidity with $\Delta_{l}^{\prime}$ temperature at the canopy layer, $\lambda$ is latent heat of vaporisation of water and $\rho$ is density of air

The set of equations are identified throughout this paper by the name CLATTER (canopy layer and total transpiration estımation routine)

Following Landsberg (1986), the net radiation beneath the $t$ th layer in the forest canopy is approximated by the Beer-Lambert Law

$$
R_{\mathrm{n}, t}=R_{\mathrm{no}} \exp \left(-k \sum_{l=1}^{l} L_{l}\right)^{*}
$$

where $R_{\mathrm{n}, t}$ is the radiation beneath the $t$ th canopy layer, $R_{\mathrm{n} . \mathrm{o}}$ is the net radiation above the canopy, $k$ is an extınction coefficient (taken here as 06 ), $L_{i}^{*}$ is the leaf area index of layer $J$ (where $J=1$ to $t$ )

This value of $k$ combined with the $L^{*}$ estimated a residual net radiation at the forest floor of $25 \%$ wholly consistent with measurements made in that position in this forest by Shuttleworth et al (1984b) from

For each of the canopy layers stomatal conductance, $\left(g_{c}\right)$ was calculated

$g_{\mathrm{c} t}=L_{l}^{*} g_{\mathrm{s} \text {, }}$

where $L_{t}^{*}$ is the leaf area index of a given canopy layer and $g_{\mathrm{s}_{t}}$ is the leaf stomatal conductance a given canopy layer 
Leaf boundary-layer conductances made in individual canopy layers were scaled up in exactly the same way to give a canopy layer conductance

\section{Stomatal conductance}

Roberts et al (1990) describe results from a detaled investigation of stomatal conductance $\left(g_{\mathrm{s}}\right)$ for rainforest canopy at the Reserva Ducke site used in this study These results encompassed the diurnal variation encountered throughout the forest canopy, and were collected in three measurement per1ods coinciding with different seasons in 1983, 1984 and 1985 Differences in $g_{s}$ between seasons were observed to be small, but there was a substantial variation associated with position in the canopy, and large diurnal trends which are correlated with diurnal changes in solar radiation and atmospheric humıdity deficit

Roberts et al (1990) report regression equations (Table 1) which relate $g_{\mathrm{s}}$ to

Table 1

Linear regression statıstıcs for stomatal conductance $\left(\mathrm{mmol} \mathrm{m}^{-2} \mathrm{~s}^{-1}\right)$ with specific humıdıty deficit $\left(\mathrm{g} \mathrm{kg}^{-1}\right)$ in five radiation classes for five canopy levels

\begin{tabular}{|c|c|c|c|}
\hline $\begin{array}{l}\text { Solar radiation class } \\
\left(\mathrm{W} \mathrm{m}^{-2}\right)\end{array}$ & Canopy Level & Offset & Slope \\
\hline $700-1000$ & $\begin{array}{l}1 \\
2 \\
3 \\
4 \\
5\end{array}$ & $\begin{array}{l}459 \\
259 \\
244 \\
204 \\
244\end{array}$ & $\begin{array}{l}-232 \\
-120 \\
-108 \\
-108 \\
-108\end{array}$ \\
\hline $600-700$ & $\begin{array}{l}1 \\
2 \\
3 \\
4 \\
5\end{array}$ & $\begin{array}{l}327 \\
208 \\
244 \\
204 \\
244\end{array}$ & $\begin{array}{r}-124 \\
-88 \\
-108 \\
-108 \\
-108\end{array}$ \\
\hline $500-600$ & $\begin{array}{l}1 \\
2 \\
3 \\
4 \\
5\end{array}$ & $\begin{array}{l}310 \\
226 \\
254 \\
214 \\
254\end{array}$ & $\begin{array}{l}-132 \\
-116 \\
-140 \\
-140 \\
-140\end{array}$ \\
\hline $400-500$ & $\begin{array}{l}1 \\
2 \\
3 \\
4 \\
5\end{array}$ & $\begin{array}{l}313 \\
194 \\
175 \\
135 \\
175\end{array}$ & $\begin{array}{r}-128 \\
-128 \\
-76 \\
-76 \\
-76\end{array}$ \\
\hline $0-400$ & $\begin{array}{l}1 \\
2 \\
3 \\
4 \\
5\end{array}$ & $\begin{array}{l}233 \\
137 \\
133 \\
133 \\
133\end{array}$ & $\begin{array}{l}-76 \\
-80 \\
-60 \\
-60 \\
-60\end{array}$ \\
\hline
\end{tabular}


specific humidity deficit at all five canopy heights for a range of above-canopy radiation classes When calculating transpiration from the forest canopy, the appropriate values of stomatal conductance were calculated for each canopy level from these equations using values of above-canopy solar radiation and specific humidity deficit

\section{Boundary-layer conductance}

Boundary-layer conductance $\left(g_{\mathrm{a}}\right)$ was also determined throughout the forest canopy by Roberts et al (1990), using measurements of weight losses from wetted paper leaf replicas $g_{\mathrm{a}}$ increased sharply from the forest floor to the top of the canopy, a change expected as $g_{\mathrm{a}}$ increases with higher wind speeds However at any particular canopy level there were insufficient data to allow a definition of any subsidiary relationship between $g_{\mathrm{a}}$ and wind speed For the purposes of calculating transpiration in this study a fixed $g_{\mathrm{a}}$ value has therefore been selected for the appropriate level from the profile given by Roberts et al (1990), and this value is given in Table 2 These values retain the discontinuity in $g_{\mathrm{a}}$ noted by Roberts et al (1990), with $g_{\mathrm{a}}$ greater at $20 \mathrm{~m}$ than higher in the canopy at $30 \mathrm{~m}$ The value of $g_{\mathrm{a}}$ is multiplied by the value of $L^{*}$ appropriate to each level to give $g_{\mathrm{a}}$ used in Eq (1)

\section{Leaf area index}

\section{Derivation from literature}

Estimates of leaf area index $\left(L^{*}\right)$ and its vertical distribution for forest sites near Manaus were derived from data previously published by Klinge (1973) and Klinge et al (1975), as shown in Table 3 Klinge et al (1975) provide information on the distribution of leaf fresh weight in six canopy strata The assumption is here made that the dry weight of the foliage constitutes $50 \%$ of fresh weight The leaf dry weight in each stratum is then converted to $L^{*}$ using values for specific leaf area given by Medina and Klinge (1983)

The vertical canopy distribution derived from data given by Klinge (1973)

Table 2

Boundary-layer conductances $\mathrm{g}_{\mathbf{d}},\left(\mathrm{mmol} \mathrm{m}^{-2} \mathrm{~s}^{-1}\right)$ at five canopy positions for the forest at Reserva Ducke

\begin{tabular}{llc}
\hline Canopy level & Height $(\mathrm{m})$ & $\mathrm{g}_{\mathrm{a}}$ \\
\hline 1 & 357 & $1320(242)$ \\
2 & 305 & $960(223)$ \\
3 & 232 & $1040(175)$ \\
4 & 134 & $800(93)$ \\
5 & 15 & $240(28)$ \\
\hline
\end{tabular}

Values in brackets represent one standard deviation 
Table 3

Derivation of Leaf Area Index $\left(L^{*}\right)$ in six canopy layers in a Terra Firme ranforest near Manaus

\begin{tabular}{llcll}
\hline Canopy Layer & $\begin{array}{l}\text { Height } \\
(\mathrm{m})\end{array}$ & $\begin{array}{l}\text { Dry weight } \\
\left(\mathrm{kghd}^{-1}\right)\end{array}$ & $\begin{array}{l}\text { Specific ledf area } \\
\left(\mathrm{cm}^{2} \mathrm{~g}^{-1}\right)\end{array}$ & $L^{*}$ \\
\hline A & $237-354$ & 1150 & 55 & 063 \\
B & $167-259$ & 3550 & 65 & 231 \\
C1 & $84-145$ & 1950 & 75 & 146 \\
C2 & $36-59$ & 1000 & 85 & 085 \\
D & $17-30$ & 1100 & 95 & 104 \\
E & $01-10$ & 300 & 105 & 031 \\
\hline
\end{tabular}

Data drawn from Klinge (1973) Klınge et al (1975) Medına and Klinge (1983)

and Klinge et al (1975) was allocated to five canopy layers as shown in Fig 1(a) which also shows the measurement points of the micrometeorological profile For the middle three layers of the canopy, Levels 2, 3 and 4 the measurements are made in the middle of the layer, but towards the base of the layer in the highest and lowest layers, Level 1 and 5 Figure 1(b) shows the downward cumulative distribution in the forest canopy of $L^{*}$, the total being 661

Conceicao (1977), also working in the Manaus region, derived a value of 66

(a)

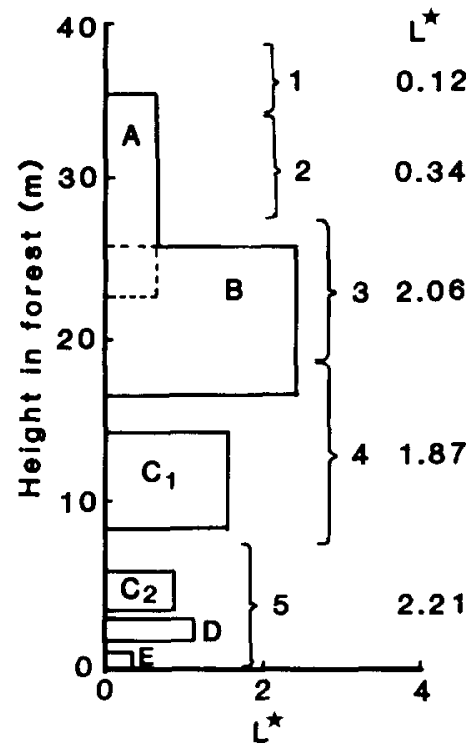

(b) 
for $L^{*}$ from measurements of radiation interception by the forest canopy assuming a value of 065 for the extinction coefficient, $k$ Recently McWilliam et al (1993) made direct determınatıons of $L^{*}$ for a height profile through a forest $60 \mathrm{~km}$ from the Reserva Ducke which had been selected to be on the same part of the toposequence as this experimental site in the Reserva Ducke The total $L^{*}$ they report is $57 \pm 05$, and shows a similar cumulative vertical distribution to that derived here from earlier literature (Fig 1(b)) The lower value of total $L^{*}$ reported by McWilliam et al (1993) may well reflect the fact that their determination was made at the end of the dry season when leaf fall is at a maximum in the central Amazon The values of specific leaf area determined by McWillıam et al (1993) also compare well with those used here, see Table 3

\section{Determination of $\mathrm{L}^{*}$ from litter fall}

The magnitude of $L^{*}$ was also determined from measurements made of areas of fallen leaves collected in 20 litter trays $\left(011 \mathrm{~m}^{2}\right)$ at approximately every 2 weeks between July 1984 and July 1986 After collection in the forest and surface drying, the area of litter leaves was determined with a LI-3100 (Licor, Lincoln, NE) leaf area machine Figure 2 shows that the cumulative litter $L^{*}$ collected over this 2 year period was 122 suggesting that $L^{*}$ is on average 61

Clearly there is a good deal of consistency in these values However, the underlying philosophy of the present modelling studies is to explore the extent to which published data on physiological behaviour, canopy quantities and

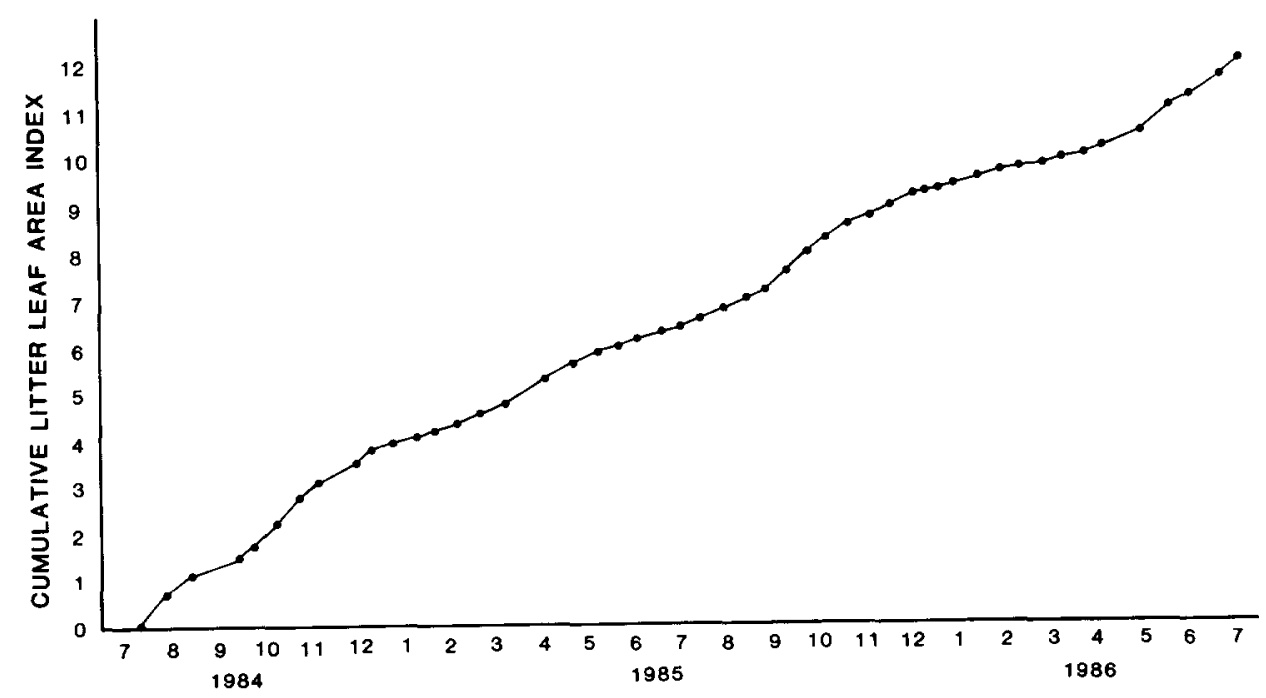

Fig 2 Cumulative litter leaf ared index for the Reserva Ducke sıte, 1984-1986 
forest microclimate can be used to estimate transpiration Consequently the $L^{*}$ values used here in CLATTER are those derived from the studies reported by Klinge (1973) and Klinge et al (1975) In view of the peak of litterfall in the dry season $L^{*}$ for inputting into CLATTER for September 1983 was reduced by $20 \%$ in all canopy layers

\section{Model sensitivity}

Investigations were made of the sensitivity of the calculated transpiration from the CLATTER model to changes in the input variables net radiation $\left(R_{\mathrm{n}}\right)$, specific humidity deficit $(\delta q)$, alr temperature $\left(T_{\mathrm{a}}\right)$, surface conductance $\left(g_{\mathrm{c}}\right)$ and boundary-layer conductance $\left(g_{\mathrm{a}}\right)$ Values were changed independently in steps of $5 \%$ from $25 \%$ below to $25 \%$ above the original values

\section{Direct measurements of transpiration}

Direct measurements of transpiration were provided by the 'Hydra', a battery-powered eddy correlation flux measurement device mounted above the forest at a height of $484 \mathrm{~m}$ The 'Hydra' system consisted of a ventilated sonic anemometer, a single beam infrared absorption hygrometer, a thermocouple thermometer and two Gill propeller anemometers Further detalls of this measurement system. and procedures used in data processing are given by Shuttleworth et al (1984a) For the purposes of this study the hourly average of latent heat flux measured by the 'Hydra' in dry conditions, viz the transpiration, were used for comparison with calculated values given by CLATTER, and simplified versions of that model

\section{Model simplification}

The same 'Hydra' data were used both to evaluate the performance of CLATTER and a series of simpler models to assess the level of simplification able to calculate transpiration to an acceptable level

Four alternative models were evaluated in each of which the canopy is represented as a single layer from which transpiration is calculated using the Monteith-Penman formula The entire canopy, absorbing $975 \%$ of net radiation is treated as a single layer with $L^{*}$ equal to 66

Four separate models were evaluated, as follows

\section{Model 1}

In this model $g_{\mathrm{s}}$ and $g_{\mathrm{a}}$ of each canopy layer are multiplied by the value of $L^{*}$, for each canopy layer and the resultıng conductances summed for use in a single-layer form of Eq (1) Air temperature $\left(T_{\mathrm{a}}\right)$ and humidity deficit $(\delta q)$ required for the equation are mean values derived from five measurement levels in the forest 


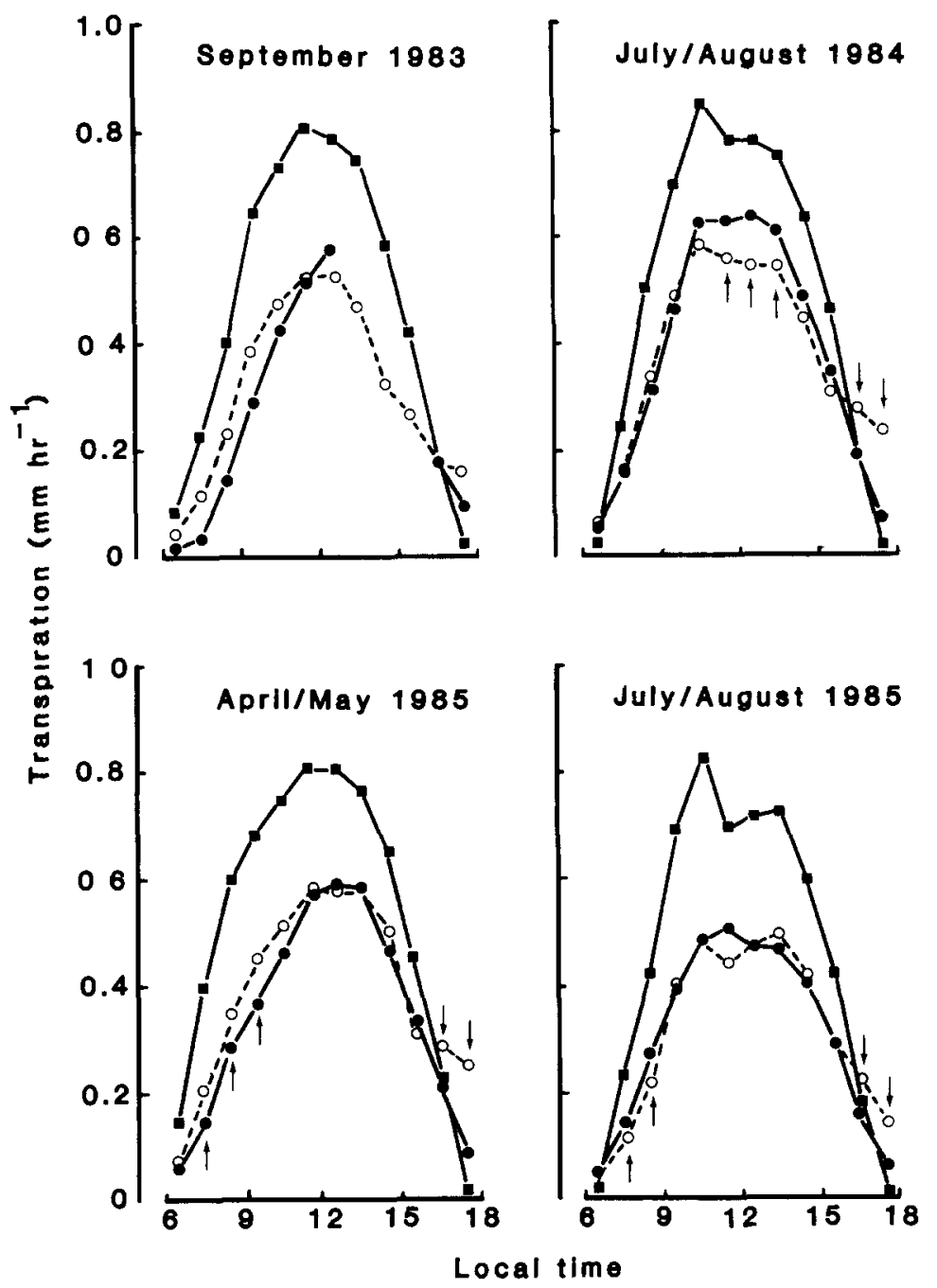

Fig 3 Comparisons of hourly transpiration measured by an eddy correlation device 'Hydra' (- - ) and estımated from CLATTER (O - - O) for four measurement periods at the Reserva Ducke, Manaus, Brazil Where the standard errors of values differ this is indicated by an arrow Net radiation averaged for the same hours, expressed as a transpiration equivalent, is also shown (ם)

\section{Model 2}

This model is identical to Model 1 except that the average through-canopy values for $T_{\mathrm{a}}$ and $\delta q$ are replaced by the measured above-canopy values

\section{Model 3}

For this model $g_{\mathrm{s}}$ and $g_{\mathrm{a}}$ for all five canopy levels are first averaged and then 
Table 4

Mean dally transpiration rates $\left(\mathrm{mm} \mathrm{day}^{-1}\right.$ ) measured with an eddy correlation device ('Hydra) compared with means of dally estımates from d transpiration model (CLATTER) tor the same periods

\begin{tabular}{lll}
\hline Period & Hydra & Model \\
\hline September 1983 & 227 & 264 \\
July August 1984 & 455 & 454 \\
April May 1985 & 416 & 465 \\
July A August 1985 & 371 & 377 \\
\hline
\end{tabular}

multiplied by the total value of $L^{*}$ The resulting canopy conductances are used in Eq (1), with $T_{\mathrm{a}}$ and $\delta q$ specified as the average values from five canopy levels as in Model 1

\section{Model 4}

This model is identical to Model 3 except that the measured above-canopy values of $T_{\mathrm{a}}$ and $\delta q$ are used instead of the average through-canopy values

\section{Results}

\section{Model Performance}

Calculations were made of hourly transpiration using CLATTER for four periods, namely September 1983, July/August 1984, April/May 1985 and July/August 1985 Figure 3 shows a comparison between hourly transpiration averaged for several days compared with the measured transpiration given by the 'Hydra' eddy correlation device for the same periods

There is good agreement between measured transpiration and that est1mated by CLATTER, although there is a tendency for CLATTER to overestimate transpiration at the ends of the day One explanation for this overestimation is that CLATTER makes no allowance for the fraction of net radiation lost as heat storage in the forest biomass, or in the air within the trunk space Moore and Fisch (1986) estimated that the hourly energy flux into and out of storage is frequently above $50 \mathrm{~W} \mathrm{~m}^{-2}$, but sometımes reaches $80 \mathrm{~W} \mathrm{~m}^{-2}$ in the early morning and late afternoon, and may constitute over $50 \%$ of the net radiation at these times The hourly differences in transpiration measured by the 'Hydra' and that estimated by CLATTER on some occasions exceeds $01 \mathrm{~mm} \mathrm{~h}^{-1}$, which is equivalent to $70 \mathrm{~W} \mathrm{~m}^{-2}$

Table 4 shows the mean daily transpiration totals estimated from the CLATTER and that measured by the 'Hydra' for the four 16 periods and, apart from the 1983 values, the correspondence is excellent The numbers of 


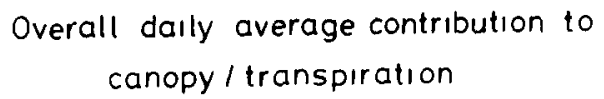

\begin{tabular}{|c|c|c|}
\hline & September & 198 \\
\hline E. & July / August & 19 \\
\hline 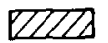 & April / May & 19 \\
\hline & July /August & \\
\hline
\end{tabular}

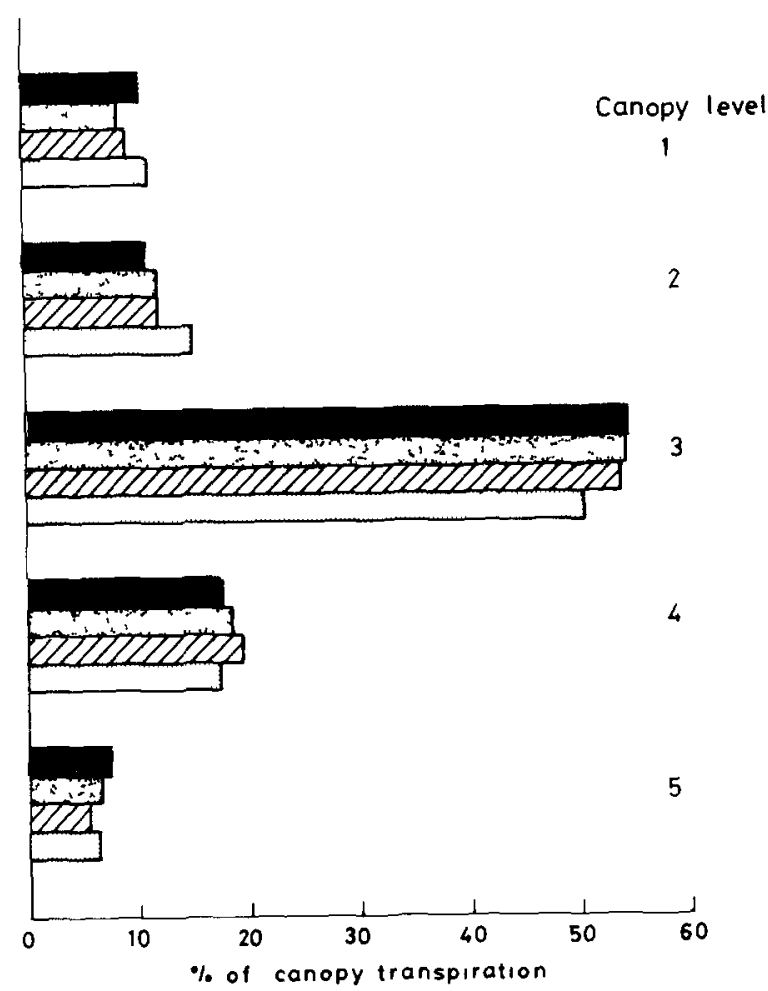

Fig 4 Estimates of the distribution of total forest transpiration to the five canopy layers in four measurement periods

hours data avallable for analysis in each period was September 1983, 15, July and August 1984, 118, April and May 1985, 97, July and August 1985, 49

Distributlon of within-canopy transpiration

Estımates are avalable of the distribution of transpiration flux from each of 
July / August 1984

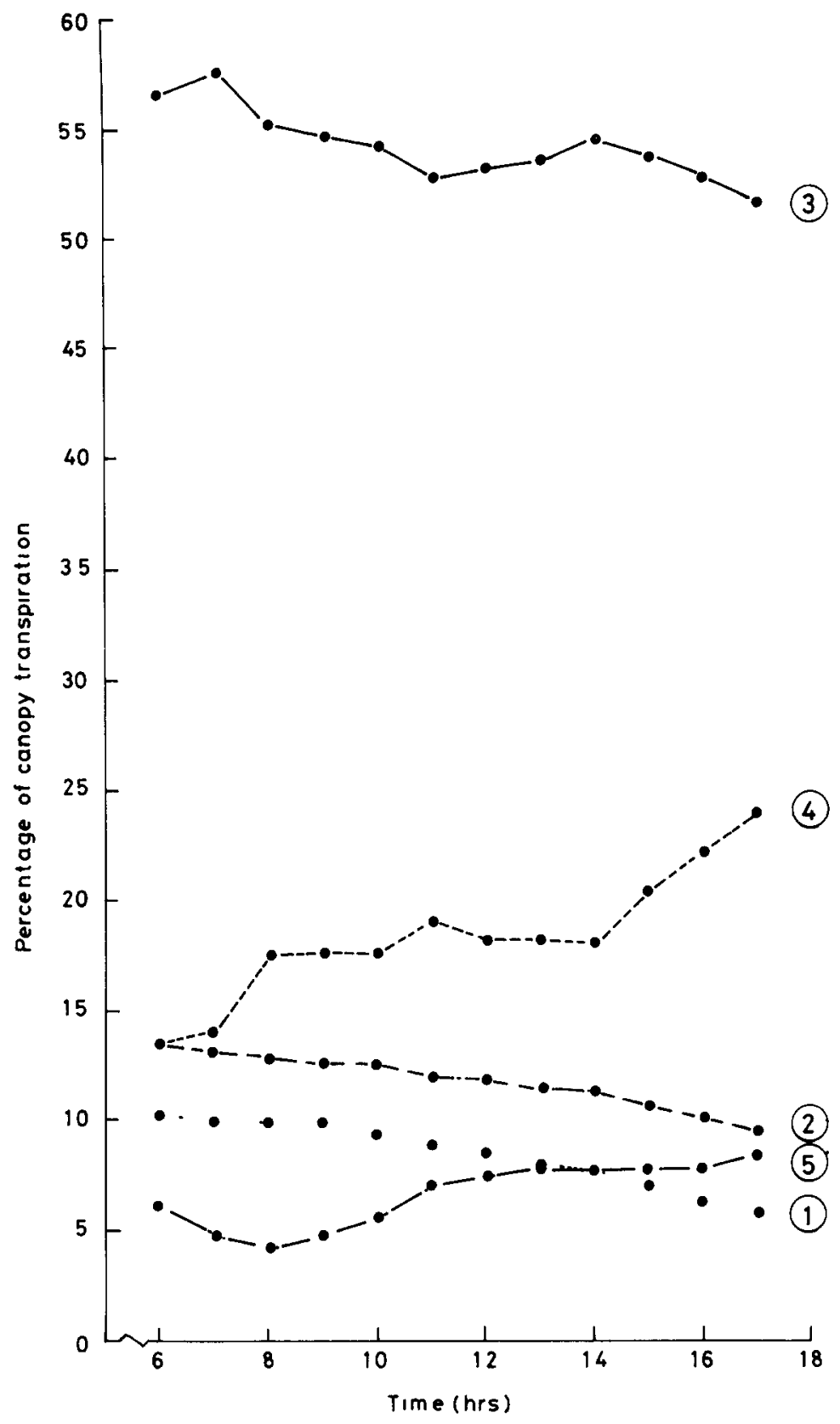

Fig 5 Estımates of the diurnal trends of percentage contribution of individual canopy layers to total canopy transpiration during July/August 1984 
the five forest canopy layers for each of the four study periods The distribution of $L^{*}$ and the absorption of avallable energy through the canopy do not change in CLATTER from one period to the next so little variation in the relative contributions of each canopy layer is expected (Fig 4) The middle layer of the canopy, which has the largest fraction of $L^{*}$ and has the greatest absorption of avallable energy, is calculated to contribute over $50 \%$ to the total canopy transpiration

Figure 5 shows hour by hour estımates for each of the canopy layers for one of the study periods, and indicates a small percentage fall in the contribution of the three upper canopy layers during the day, while the contribution from the lowest two layers rises These changes in contribution are a consequence of

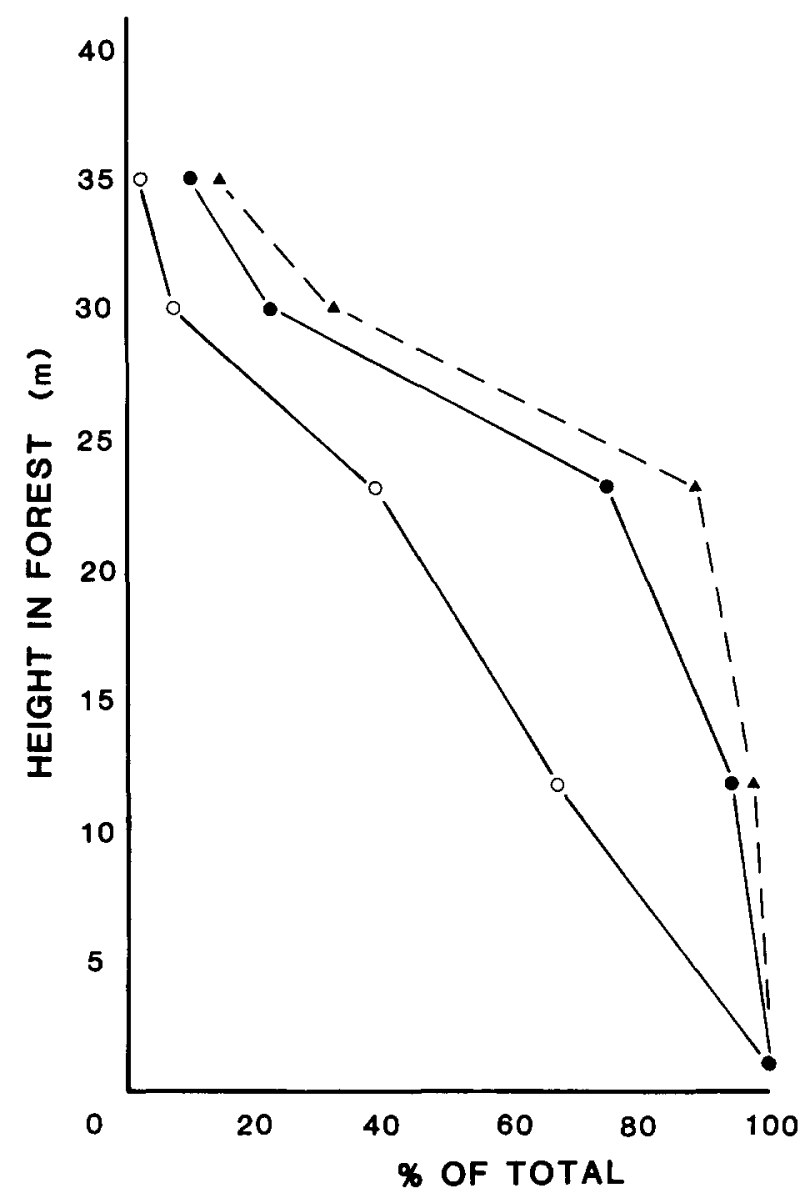

Fig 6 A comparison of the vertical downward distribution of cumulative leaf area index

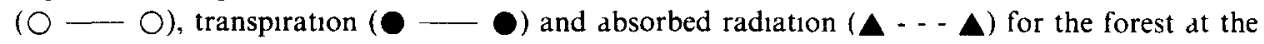
Reserva Ducke, Manaus, Brazıl 
the fall in $g_{\mathrm{s}}$ in response to atmospheric humidity deficit which is known to occur most markedly in the upper canopy (see Table 1), and is most obvious in the mid-afternoon when humidity deficits are greatest

The calculation of the net radiation allocated to each canopy layer is a function only of the $L^{*}$ and its vertical distribution and the light extinction coefficient Figure 6 shows that there is close similarity between the calculated pattern of cumulative canopy transpiration and that of absorbed radiation, though less similarity with cumulative $L^{*}$

There is scope for improving the calculation of net radiation absorption since it is an important control on canopy transpiration, but CLATTER is conceived to be as simple as possible because it is unlikely that data from other tropical forest studies would have the detailed information required Studies of the sensitivity of radiation absorption of different canopy properties are rare, but a recent study by Wang and Jarvis (1990) showed that, for a coniferous forest canopy, $L^{*}$ and its distribution are important but that crown shape and leaf inclination angle are less so

Figure 7 shows the sensitivity of the transpiration calculated by CLATTER to the values of the conductances $g_{c}$ and $g_{\mathrm{a}}$ There is clearly a significant

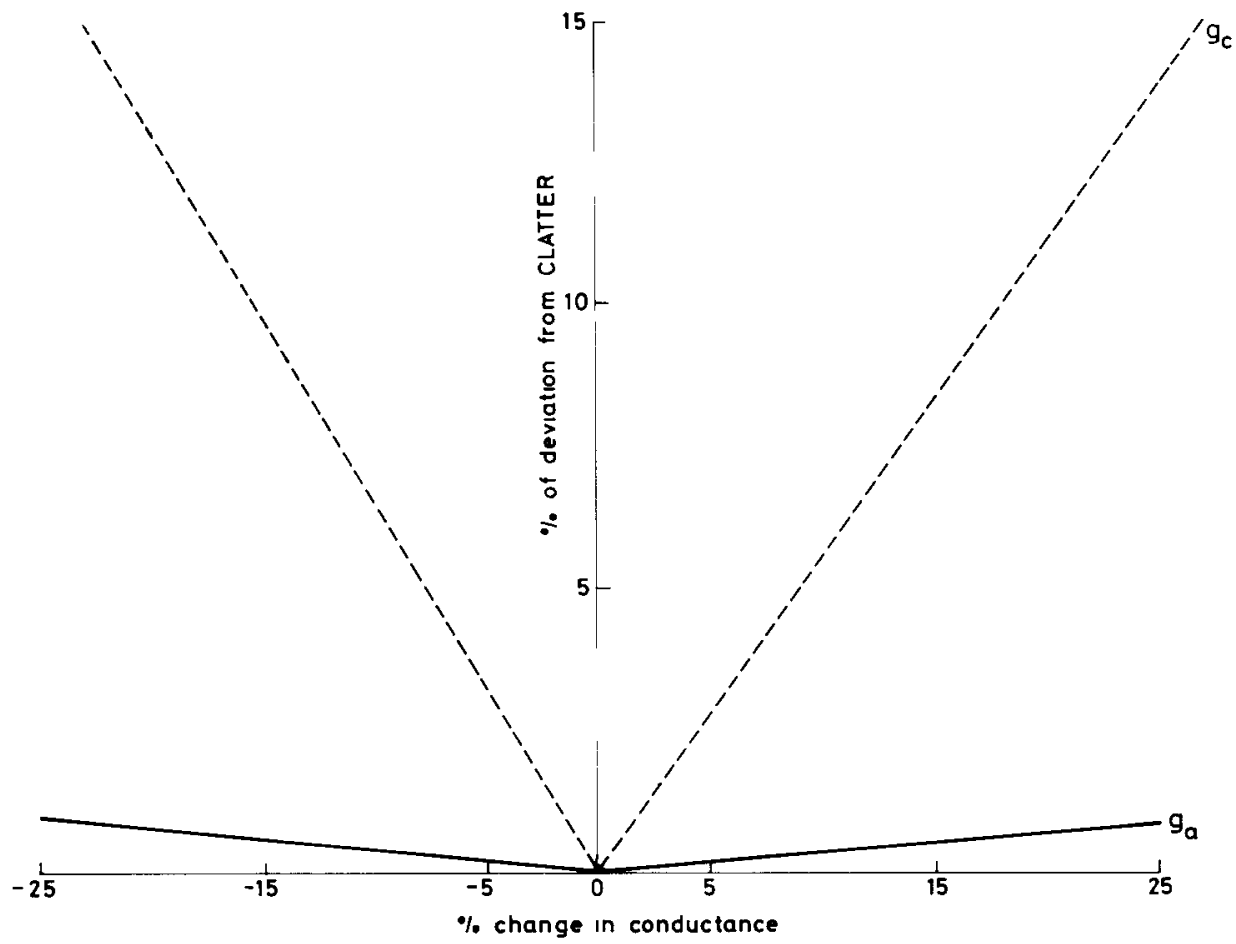

Fig 7 Sensitivity of transpiration estımated from the CLATTER model to changes in surface conductance $\left(g_{c}\right)$ and boundary-layer conductance $\left(g_{d}\right)$ 
sensitivity to the value of the surface conductance $\left(g_{c}\right)$, and hence to the value of leaf area index, $L^{*}$, or the stomatal conductance, $g_{s}$ In contrast the calculated transpiration is insensitive to the value of the boundary-layer conductance, $g_{\mathrm{d}}$ Examination of the sensitivity of the estimated transpiration to the meteorological variables ( $\left.F_{1 g} 8\right)$ shows that uncertainties in the value of net radiation are more important than are those in specific humidity deficit or temperature

Figure 9 shows comparisons between transpiration measured using the 'Hydra' and that estımated from five different transpiration models, including CLATTER While the agreement between measured transpiration and that estımated by CLATTER is good, progressive simplification of the calculation procedure clearly leads to larger discrepancies with respect to measured transpiration The simplest model, Model 4, in which $g_{\mathrm{s}}$ is averaged through the canopy, then multiplied by the total $L^{*}$, and transpiration calculated using weather variables measured above the canopy, produces estımates of transpiration considerably larger than those measured Less simple models, partıcularly those using an average of the measured microclimate through the canopy, give agreement with measurements, but do not match the comparison given by the full canopy transpiration model The regression statistics for the relationships between measurements of transpiration made with 'Hydra' and those estimated by CLATTER and the four simplified models are given in Table 5

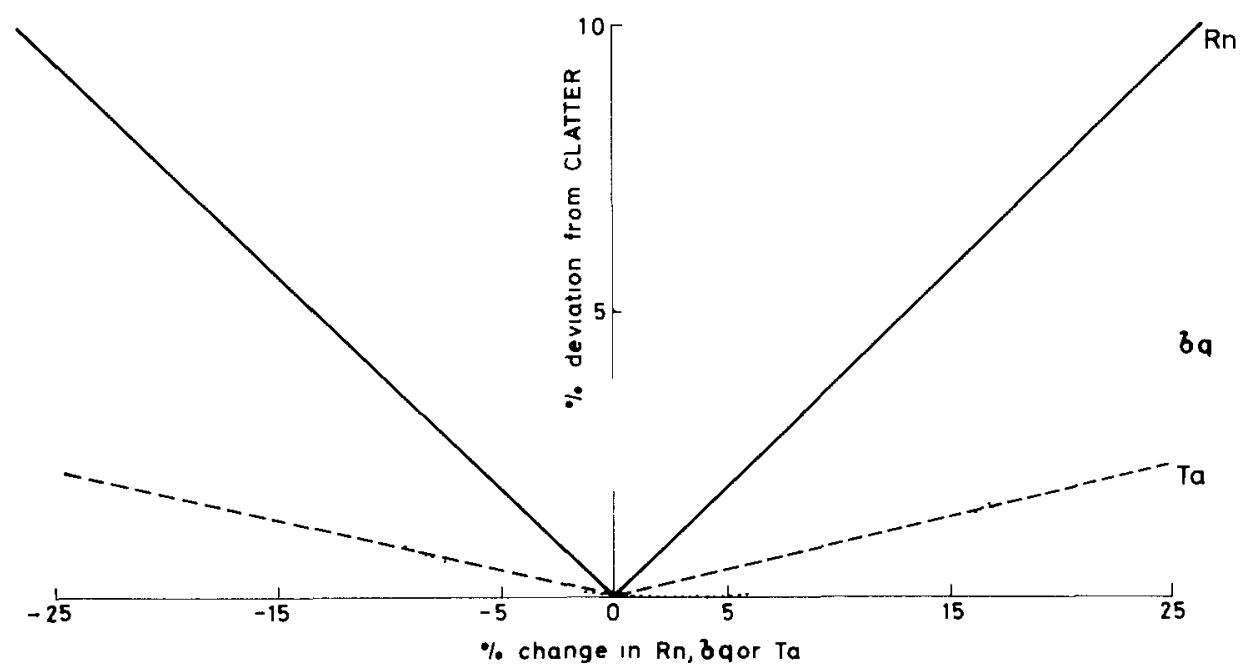

Fig 8 Sensitivity of transpiration estımated from the CLATTER model to changes in net radiation $\left(R_{\mathrm{n}}\right)$ specific humidity deficit $(\delta q)$ and air temperature $\left(T_{\mathrm{d}}\right)$ 


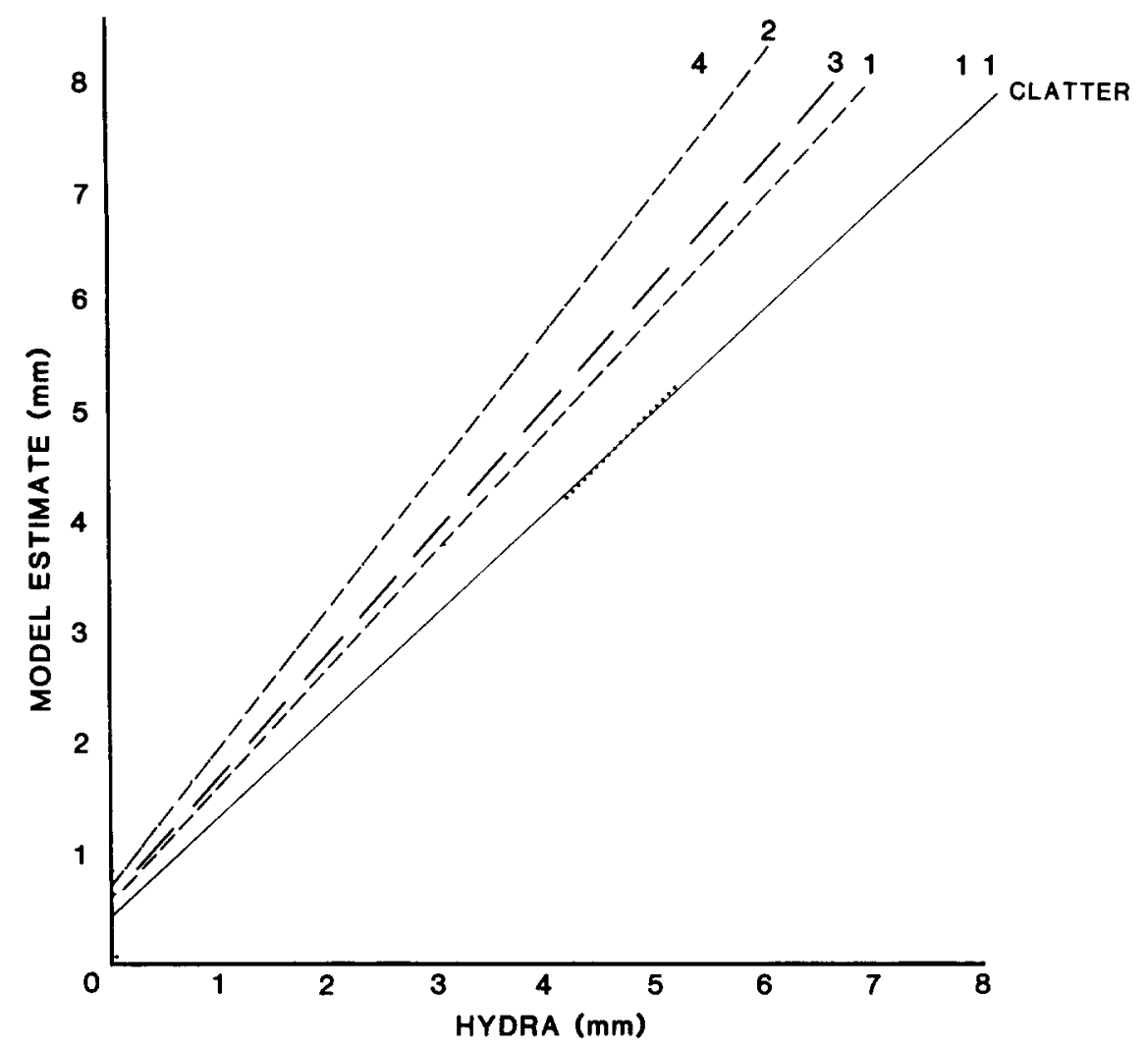

Fig 9 Comparison of transpiration measured with an eddy correlation device, Hydra' with that estımated by CLATTER and four simple derivatıves of CLATTER. Models 1-4 (see text for detalls)

\section{Discussion}

The studies reported here clearly show the ability successfully to combine physiological data taken in a complex forest canopy with within and abovecanopy measurements of the forest microclımate to provide valid estımates of forest transpiration The estımates from a multılayer calculation, such as CLATTER, for periods as short as an hour show systematic error Longer term estımates, such as over a day or week, are more accurately predicted, and this suggests such calculation procedures may well have considerable value $\mathrm{A}$ major constraint in using the multilayer model for other tropical rain forests is the high demand withın the model for detalled physiological and microclimatic data

Simplifyıng the model by limitıng the amount of required information on $L^{*}$ distribution through the canopy, and using single point values for weather variables, proved unsuccessful in this case In less complex forest canopies the 
Table 5

Regression statıstics for transpiration ( 1 ) estımated from a canopy transpiration model and simplified derivatives in comparison with measured values ( $x$ ) from an eddy correlation device Hydra

\begin{tabular}{|c|c|c|}
\hline Model & Equation & $r^{2}$ \\
\hline CLATTER & $\begin{aligned} 1= & 0456+0896 x \\
& (0140)(0044)\end{aligned}$ & 093 \\
\hline 1 & $\begin{array}{r}1=0611+1049 x \\
(0169)(0052)\end{array}$ & 092 \\
\hline 2 & $\begin{array}{r}l= \\
\quad 0581+1110 x \\
(0164)(0052)\end{array}$ & 093 \\
\hline 3 & $\begin{aligned} 1= & 0731+12581 \\
& (0220)(0069)\end{aligned}$ & 091 \\
\hline 4 & $\begin{aligned} 1= & 0773+13111 \\
& (0214)(0067)\end{aligned}$ & 092 \\
\hline
\end{tabular}

Numbers in brackets are standard errors for intercept and lope Both $x$ and 1 are in millımetres per day

data requirements are much less stringent Roberts and Rosier (1993) for example, using data from Eucalyptus plantations in South India, found little difference in calculated transpiration between the multilayer calculation of CLATTER and the simpler calculation procedures used here The simpler model was justified in that case because there were only small differences in $g$, through the Eucalyptus canopy This meant that the $g_{s}$ from any of the canopy layers could be multiplied by the total $L^{*}$ to give the canopy conductance, $g_{\mathrm{c}}$ Moreover, the canopy was open and well-ventılated, and only small gradients of temperature and humidity deficit exist, thus justifying the use of single, above-canopy values of these variables

In the present study the very detaled information on within-canopy conductances and microclimate arıse from a comprehensive, multidisciplinary experımental programme, and such sets of datd are rare This implies that a multi-layer calculation such as CLATTER will have only a limited role in predicting the transpiration of tropical forest using pre-existing published data This is not necessarily the case since, in the decade since the review by Doley (1981), a substantıal number of reports have appeared giving informdtion on aspects of the physiological behaviour of tropical forest species Detalled examination of this information is now warranted, particularly with regard to the magnitude of stomatal conductance and its functional relationships to weather variables such as solar radiation and vapour pressure deficit In contrast, much less new data has emerged on $L^{*}$ and on its vertical distribution in tropical forests, and on the behaviour of microclimate through forests It is the shortage of this type of information which most seriously limits the usefulness of through canopy calculation models such as CLATTER However, it may well be possible to determine the form of the withın-canopy normalised profiles of parameters such as temperature and 
humidity deficit as empirical functions of the parameter measured over the forest or in a nearby clearing, an approach which seems likely to be a worthwhile research area for the future

In recent years, measurements of temperature and humidity deficit grad1ents through vegetation canopies have recorded the existence of upward fluxes of latent heat which are counter to the measured gradients inside the canopy (e g Denmead and Bradley, 1985). 1mplyıng that concentration gradient, diffusion theory ( $\mathrm{K}$ theory) is not appropriate to describe exchange processes within canopies (e g Raupach and Finnigan, 1988, Raupdch, 1989) This is not a problem in the present case for CLATTER (in which the traditional gradient diffusion mechanism is assumed), because measured values of temperature and humidity deficit are used to calculate transpiration at each level There is, therefore, no need to separately model to predict these variables, see, for example Raupach (1989) Such predictions of within-canopy microclimate would be preferable, and may be necessary, in situations where data are not as complete as in this study This remains to be evaluated

Because there is good agreement between the values of transpiration est1mated by CLATTER and those measured, it is not surprising that an estimate of the proportion of net radiation used in transpiration process using CLATTER compares well with measured ratios reported by Shuttleworth et al (1984a) and Shuttleworth (1988), who report between 75 and $80 \%$ for nonrany days When calculated over the daylight perıods for the 37 days for which CLATTER calculations were made in this study an average of $745 \%$ of the net radiation was required for transpiration This is a relatively high value, but not unique to tropical forests Rauner (1976), for instance, gave data for temperate broadleaf stands, some of which equalled rainforest in terms of the percentage of net radiation used in transpiration In contrast rates for coniferous forests may reach this high value only in the first part of the day, but never reach the same proportion on a dally basis (Jarvis et al , 1976) and Stewart and Thom (1973) show the ratio to be as low as $40 \%$ for Scots Pine in Thetford Forest, UK In this latter case the low value was simply owing to an inherently low surface conductance, and not necessarily assocrated with a high soil water deficit However, in other studies depletion of soll water reserves is associdted with lowered use of net radiation for forest transpiration Roberts and Rosier (1993) also estımated transpiration for Eucalyptus stands in South India and, when these were well supplied with soil water, $78 \%$ of the net radiation was used for transpiration, even though $L^{*}$ was only one third that of the present rainforest However, this ratio fell to only $17 \%$ when the solls were dry

Shuttleworth et al (1984a), commenting on their micrometeorological measurements of transpiration, stated that the proportion of net radiation used for transpiration by a rainforest which is almost always well supplied with water is rarely if ever more than $75 \%$ While Jarvis et al (1976) note that 
for irrigated farm crops the Bowen ratio is usually close to zero, implying that almost all the net radiation is used for transpiration The conclusion then, is that even moist rainforest still exerts substantial stomatal control on transpiration, a conclusion which the direct observations of $g_{s}$ Roberts et al (1990) confirm These last authors drew attention to the fact that typically values of $g_{\mathrm{s}}$ for tropical trees are not particularly high, except for the largeleaved species Gmelina and Tectona studied by Whitehead et al (1981) and Grace et al (1982) Studies of leaf water and osmotic potentials in upper canopy trees at the current Reserva Ducke study site have shown that leaf water potential can almost reach $-40 \mathrm{MPa}$ in the emergent species Piptadenia suaveolens and up to $-36 \mathrm{MPa}$ in Bocoa virldfflora an upper canopy species ( $\mathbf{J}$ Roberts and O M R Cabral, unpublished data, 1984) These values, which are taken in mid-afternoon, are close to the turgor loss point for leaves, hence plants lowering the value of $g_{s}$ to restrict transpiration and prevent leaf dessication clearly has an important role, even though soil water supply is apparently not limiting

The upper canopy layer of this forest had an $L^{*}$ of 012 and is treated as an horizontally homogenous entity in CLATTER This is a simplification as this canopy layer comprises the crowns of emergent trees which are spatially separated This will mean that the absorption of net radiation by trees in this layer and consequently the radiation levels reaching the layer below will be a function of the dimensions of the emergent trees' canopies, the spacing between emergent trees and sun angles Because of the rather low level of $L^{*}$ in the upper canopy layer no attempts have been made to account for the spatial heterogeneity in the 24 upper canopy level within CLATTER However, the configuration of emergent tree canopies can vary widely between rain forests and it is planned that derived versions of CLATTER will take account of discontinuous upper canopy layers Physiological and micrometeorological datd are becoming avalable for this development from a study in a rain forest near Maraba, Pard. Brazil This is one of the rain forest sites of the ODA-supported ABRACOS (Anglo-Brazılian Amazonian Clımate Observatıon Study) project operated by the Institute of Hydrology and collaboratıng Brazılian institutes A particular feature of this forest are Brazil nut trees (Bertholletia excelsa) which largely compose a distinct emergent layer The horizontal spatial separation between individual emergent trees is much greater than observed at the Reserva Ducke, Manaus The Brazil nut trees can have crowns up to $70 \mathrm{~m}$ in diameter and are roughly spherical in shape Preliminary observations show that above-canopy radiation is substantially attenuated by these densely foliated crowns leading to a large variation in the radiation reaching the sub-emergent tree layer In this case it will be necessary to use a more sophisticated treatment of rddiation absorption by the upper canopy layer in CLATTER

In summary, the main points arising from this study are that through 
canopy calculations of transpiration from basic plant physiological and microclimatic information closely matches measured whole canopy transpiratıon, but that calculations made with simpler models are less good

\section{Conclusions}

The multi-layer canopy transpiration model (CLATTER) gives good prediction of transpiration from tropical rain forest when compared with the eddy correlation device 'Hydra' on an hourly basis There is however divergence early and late in the daylight period probably because CLATTER makes no allowance for changes in heat storage in the forest Averaging over daily periods improves the prediction of transpiration such that estimates from CLATTER and 'Hydra' medsurements differ by only a few percent

The rigour of the model supports the assumptions made in it namely the values of fresh to dry weight ratios and specific leaf areas used to derive a canopy profile of $L^{*}$ from literdture values and the extınction coefficient of net radiation extınction $(06)$ which was used Studies of the sensitivity of CLATTER to likely errors of inputted variables revealed the greater importance of $g_{\mathrm{s}}, L^{*}$ and $R_{\mathrm{n}}$ 'with $\delta q$ and $T_{\mathrm{d}}$ less important CLATTER is insensitive to large errors in $g_{\mathrm{a}}$

The data requirements for CLATTER could not be reduced without generatıng overestimates in transpiration The most simple model which uses canopy averages of stomatal and boundary-layer conductances multiplied by total $L^{*}$ and above-canopy values only of $\delta q$ and $T_{\mathrm{d}}$ overestımated transpiration by up to $50 \%$

\section{Acknowledgements}

This study was supported financially by the Natural Environment Research Council, Britısh Council and CNPq, Brazil The work reported here was part of a multidisciplinary experiment hosted by the Instituto Nacional de Pesquisas da Amazonia (INPA) We thank the Director and Vice-Director for their hospitality and support, the Director, EMBRAPA for providing invaluable help, particularly with transport

\section{References}

Da Conceicao, P N , 1977 Alguns dspectos ecofisıologicos de floresta tropical umida de terra tirme Actd Amazonica, 7 157-178

Denmead, O T and Bradley, EF, 1985 Flux-gradient relationships in a forest canopy In B A Hutchinson and B B Hicks (Editors), The Forest Atmosphere Interaction Reidel Dordrecht pp $421-442$ 
Doley, D, 1981 Tropıcal and subtropıcal forests and woodlands In T T Koslowskı (Editor), Water Deficits and Plant Growth, Vol 7 Academıc Press, New York, pp 1-47

Gash, J H C and Stewart, J B , 1975 The average surface resistance of a pine forest derived from Bowen ratio measurements Boundary-Layer Meteorol 8 453-464

Grace J , Okalı D U U and Fasehun, F E, 1982 Stomatal conductance of two tropical trees during the wet season in Nigeria J Appl Ecol, 19 659-670

Jarvis, P G James, G B and Landsberg, J J, 1976 Conıferous Forest In J L Monteith (Edıtor), Vegetation and the Atmosphere Vol 2 Academic Press, London, pp 171-240

Klinge, H 1973 Struktur und artenreıchtum des zentralamazonischen Regenwaldes Amazonıdnd, $4283-292$

Klinge, H , Rodrıques, W A , Brunig E and Fittkau, E J , 1975 Biomass and structure in a central Amdzonıan Rain Forest In F B Golley and E Medınd (Editors) Tropical Ecological Systems Trends in Terrestrid and Aquatıc Research Springer, Berlın, pp 115-122

Landsberg J J 1986 Physiological Ecology of Forest Production Academic Press, London

McWillam, A L C Roberts J Cabral, O M R Leitao, M VBR Dd Costa, A C L, Maitell, G T and Zamparonı, C A G P , 1993 Leaf area index and above-ground biomass of terrd firme ranforest and adjacent clearings in Amdzonia Functiond Ecol 7 (in press)

Medind, E and Klinge, H 1983 Productivity of tropical forests and tropical woodlands In O L Lange, P S Nobel, C B Osmond and H Ziegler (Editors), Encyclopaedia of Plant Physiology, Volume 12D Physiological Plant Ecology IV Ecosystem Processes Mineral Cvcling Productivity, and Man s Influence Springer, Berlın pp 281-303

Monteith, J L, 1965 Evaporation and environment In The State and Movement of Water in Living Organisms Proc 19th Symp Soc Exp Biol Swansea 1964 Cambridge University Press, Cambridge, pp 205-234

Mooney H A, Bjorkman, O, Hall, A E, Medind, E and Tomlınson, P B, 1980 The study of the physiological ecology of tropical plants current status and needs Bioscience, 30 22-26

Moore C J and Fisch, G F , 1986 Estımatıng heat storage in Amazonıan tropical forest Agric For Meteorol, 38 147-169

Oberbauer, S F, Strain B R and Reichers G H, 1987 Field water relations of a wet tropical tree species Pentaclethra macroloba Oecologid, 71 369-374

Rauner, J L, 1976 Deciduous forest In J L Montelth (Editor) Vegetation and the Atmosphere Vol 2 Academic Press London, pp 241-264

Raupach M R 1989 Stand overstorey processes Philosophical Transactions of the Royal Society London, Series B, 324 175-190

Raupach M R and Finnigan, J J, 1988 Single-layer models of evaporation from plant canopies are incorrect but useful, whereas multilayer models are correct but useless discuss Aust J Plant Physiol $15705-716$

Roberts, J and Rosier, P T W 1993 Physiological studies in young Eucalyptus stands in southern Ind 1 and derived estimates of forest transpiration Agric Water Manage, (in press)

Roberts, J , Cabral, O M R and Aguiar, L de F 1990 Stomatal and boundary-layer conductances In an Amazonian terra firme rainforest $J$ Appl Ecol , 27 336- 353

Sellers, P J , Shuttleworth. W J Dorman. J L , Dalcher, A and Roberts, J M, 1989 Calıbrating the simple biosphere model for Amazonian tropical forest using field and remote sensing data $\mathrm{J}$ Appl Meteorol , 28 727-759

Shuttleworth, W J 1988 Evaporation from Amazonian rainforest Proceedings of the Royal Society London Series B 233 321-346

Shuttleworth, W J , Gash, J H C, Lloyd, C R, Moore, C J, Roberts, J M Marques, A O Fisch, G F de Pauld Silva, V Ribeiro, M N G Molıon, L C B, Abreu Sd, L D, Nobre, J C , Cabral, O M R, Pdtel, S R and de Moraes, J C 1984a Eddy correlation measurements of energy partition for Amazonian forest Q J R Meteorol Soc 110 1143-1162

Shuttleworth W J Gash J H C Lloyd C R Moore C J Roberts, J M, Marques, A O Fisch, 
G F , de Paula Sılva, V, Rıbeıro, M N G, Molıon, L C B Abreu Sd, L D , Nobre J C, Cabral. O M R , Patel, S R and de Moraes, J C , 1984b Observations of radiation exchange above and below Amazonian forest Q J R Meteorol Soc, 110 1143-1162

Stewart, J B and Thom, A S , 1973 Energy budgets in pine forest Q J R Meteorol Soc, 99 154170

Wang, Y P and Jarvis P G, 1990 Influence of crown structural properties on PAR absorption photosynthesis, and transpiration in Sitka spruce application of a model (MAESTRO) Tree Physiol 7 297-316

Whitehead, D, Okalı D U U and Fasehun F E, 1981 Stomatal response to environmental var1ables in two tropical forest species durıng the dry sedson in Nigeria J Appl Ecol, 18571587 